\title{
Reduction of Ethylene-induced Physiological Disorders of Carrots and Iceberg Lettuce by 1-Methylcyclopropene
}

\author{
X. Fan ${ }^{1}$ and J.P. Mattheis ${ }^{2}$ \\ Tree FruitResearch Laboratory, Agriculture Research Service, U.S. Department \\ of Agriculture, 1104 N. Western Avenue, Wenatchee, WA 98801 \\ Additional index words. MCP, isocoumarin, russet spotting, Lactuca sativa, Daucus carota
}

\begin{abstract}
Whole carrots (Daucus carota L.) and midrib tissues of iceberg lettuce (Lactuca sativa $L$.) were treated with $42 \mu \mathrm{mol} \cdot \mathrm{m}^{-3} \mathrm{MCP}$, then exposed to ethylene. Exposure to $42 \mu \mathrm{mol} \cdot \mathrm{m}^{-3}$ ethylene at $10^{\circ} \mathrm{C}$ increased isocoumarin content $\approx 40$-fold in both peel and pulp of nontreated carrots within 4 days, but treatment with MCP for 4 hours at $20{ }^{\circ} \mathrm{C}$ before exposure to ethylene prevented isocoumarin accumulation. Ethylene-induced acidity loss and respiration rate increase in carrots were also prevented by MCP treatment. Ethylene treatment $\left(126 \mu \mathrm{mol} \cdot \mathrm{m}^{-3}\right)$ of lettuce at $6{ }^{\circ} \mathrm{C}$ had induced russet spotting $>5 \%$ to $10 \%$ of the midrib tissue by day 3 and $30 \%$ to $35 \%$ by day 9 , while pretreatment with MCP for 4 hours at $6{ }^{\circ} \mathrm{C}$ prevented development of russet spotting. The results indicate that ethylene-induced physiological disorders and quality loss in carrots and iceberg lettuce can be prevented by MCP treatment prior to exposure to ethylene. Chemical name used: 1-methylcyclopropene (MCP).
\end{abstract}

Isocoumarin (8-hydroxy-3-methoxy-3,4dihydro-isocoumarin) accumulation, associated with bitterness in carrots (Carlton et al., 1961), is induced by exposure to ethylene (Chalutz et al., 1969; Mercier et al., 1993). An ethylene concentration of $4.2 \mu \mathrm{mol} \cdot \mathrm{m}^{-3}$ can induce significant isocoumarin formation and an isocoumarin content of $200 \mu \mathrm{g} \cdot \mathrm{g}^{-}$ ${ }^{1}$ fresh weight (FW) can be detected sensorially (Lafuente et al., 1996). Low temperature and low $\mathrm{O}_{2}$ plus high $\mathrm{CO}_{2}$ concentrations reduce ethylene-induced isocoumarin accumulation (Chalutz et al., 1969; Lafuente et al., 1996). Other factors, such as wounding and $\mathrm{O}_{2}$ concentration, do not induce, but potentiate isocoumarin formation (Lafuente et al., 1996; Theologis and Laties, 1982).

Russet spotting (RS) of lettuce is characterized by the appearance of small, reddishbrown spots or lesions on the midribs of leaves (Link and Gardner, 1919). Exposure of lettuce to ethylene induces RS (Rood, 1956). Ethylene increases the activities of phenylalanine ammonia-lyase (PAL), per-

Received for publication 7 Sept. 1999. Accepted for publication 13 Apr. 2000. We thank David Buchanan and Janie Gausman for technical assistance, and BioTechnologies for Horticulture for providing Ethylbloc $^{\circledR}$. Mention of a trademark, proprietary product, or vendor does not constitute a guarantee or warranty of the product by the U.S. Dept. of Agriculture and does not imply its approval to the exclusion of other products or vendors that also may be suitable. The cost of publishing this paper was defrayed in part by the payment of page charges. Under postal regulations, this paper therefore must be hereby marked advertisement solely to indicate this fact. ${ }^{1}$ Postdoctoral Research Associate; current address: USDA, ARS, ERRC, 600 Mermaid Lane, Wyndmoor,PA 19038.E-mail address: xfan@ arserrc.gov ${ }^{2}$ Research Plant Physiologist. E-mail address: mattheis@tfrl.ars.usda.gov oxidase (POD), and polyphenol oxidase (PPO) (Hyodo et al., 1978; Ke and Saltveit; 1989). Increased PAL activity promotes synthesis of cinnamic acid and derivatives via the shikimic acid pathway. These compounds are then available for lignin synthesis. Ethylene-induced POD activity is correlated with increased lignin formation and cell wall thickening, one of the characteristics of RS. Other products of the shikimate pathway, such as flavonoids and chlorogenic acid, are oxidized by PPO to form brown compounds. Ethylene also induces indole-3-acetic acid (IAA) oxidase activity and oxidation of internal IAA (Ke and Saltveit, 1989). Reduced IAA concentration may increase lettuce sensitivity to ethylene and RS.

The accumulation of isocoumarin in carrots and the incidence of RS of lettuce can be reduced by avoiding exposure to ethylene and to other stresses that induce ethylene production. Unfortunately, ethylene is often present in the environment where carrots and lettuce are stored, and stresses such as disease, wounding, and adverse temperatures are often encountered during the harvest and handling processes. The ethylene action inhibitor, MCP (Sisler and Blankenship, 1996; Sisler and Serek, 1997), inhibits senescence of fruits (Abdi et al., 1998; Fan et al., 1999; Golding et al., 1998) and vegetables (Fan and Mattheis, 2000). Treatment with MCP prevents ethylene-induced yellowing in broccoli (Brassica oleracea Italica Group) (Fan and Mattheis, 2000; Ku and Wills, 1999) but does not prevent development of many negative ethylene effects on orange [Citrus sinensis (L.) Osbeck] fruit during storage (Porat et al., 1999). The objective of this study was to determine whether inhibition of ethylene action by MCP reduces isocoumarin accumulation in carrots and RS development in lettuce.
Carrotexperiments. 'Touchon' carrots were harvested from a local farm, surface sterilized with $0.01 \% \mathrm{NaOCl}$ for $2 \mathrm{~min}$, rinsed twice with distilled water, then placed in 20-L glass jars. To generate MCP, Ethylbloc ${ }^{\circledR}$ (Floralife, Walterboro, S.C.) powder sufficient to generate $42 \mu \mathrm{mol} \cdot \mathrm{m}^{-3} \mathrm{MCP}$ inside a 20 -L glass jar was added to a $10-\mathrm{mL}$ test tube. The tube was sealed with a rubber septum, then placed inside the jar containing carrots. Buffer solution (Floralife) was injected through the septum into the tube, then a layer of Handiwrap ${ }^{\circledR}$ (S.C. Johnson and Son, Racine, Wis.) was loosely placed over the mouth of the jar and secured with a rubber band. The loose wrap allowed the septum to be removed while the jar was sealed; then three more layers of wrap were placed over the mouth of the jar and secured with rubber bands. The same sealing procedure was used for jars containing carrots exposed only to air during the 4-h treatment period at $20^{\circ} \mathrm{C}$.

The concentration of MCP in the jars was measured using a gas chromatograph (GC) (HP 5880, Hewlett Packard, Avondale, Pa.) equipped with a glass column (45-cm length, 0.32-cm diameter) packed with Porapak Q, 80-100 mesh (Alltech Associates, Deerfield, Ill.). A $0.5-\mathrm{mL}$ sample of headspace was removed from the jar and injected into the GC prior to unsealing the jar at the end of the 4-h treatment period. Temperatures for the GC injector, oven, and flame ionization detector (FID) were 100,130 , and $200^{\circ} \mathrm{C}$, respectively. Flow rates for $\mathrm{N}_{2}$ carrier, $\mathrm{H}_{2}$, and air were 25 , 30 , and $300 \mathrm{~mL} \cdot \mathrm{min}^{-1}$, respectively. A 1-butene standard (Scott, Plumsteadville, Pa.) was used to generate a response factor and MCP quantification was based on this value.

After removal from the $20-\mathrm{L}$ jars, four replicate $(\approx 400 \mathrm{~g}$ each) samples were placed in 4 -L glass jars and incubated at $10{ }^{\circ} \mathrm{C}$ with a continuous flow at $5 \mathrm{~L} \cdot \mathrm{h}^{-1}$ of $42 \mu \mathrm{mol} \cdot \mathrm{m}^{-3}$ ethylene in air or of air alone. The gas stream was humidified by passing through a water column prior to entering the jars. There were four treatments utilizing the carrots previously exposed to air or MCP: air, MCP then air, continuous ethylene, or MCP followed by continuous ethylene. The concentration of $\mathrm{CO}_{2}$ was analyzed periodically by injecting 1-mL gas samples collected from the jar outflow into a gas chromatograph (HP 5890, Hewlett Packard) equipped with a methanizer (John T. Booker, Austin, Texas) and a 60-cm stainless steel column ( $2 \mathrm{~mm}$ inside diameter) packed with Porapak Q (80-100 mesh). Gas flows for $\mathrm{N}_{2}, \mathrm{H}_{2}$, and air were 65,30 , and $300 \mathrm{~mL} \cdot \mathrm{min}^{-1}$, respectively, and oven, injector, and FID temperatures were 30,50 , and $200{ }^{\circ} \mathrm{C}$, respectively. Peel (3 g) and pulp (6 g) samples were frozen in liquid nitrogen and stored at $-20{ }^{\circ} \mathrm{C}$ before extraction and analysis of isocoumarin (Lafuente et al., 1996; Sondheimer, 1957). The samples were extracted overnight with 10 $m L$ HPLC-grade hexane. The solution was decanted and isocoumarin re-extracted with an equal volume of $80 \%$ ethanol. Absorbance of the ethanol layer at $267 \mathrm{~nm}$ was measured 
using a spectrophotometer (HP8451A; Hewlett Packard, Palo Alto, Calif.). Isocoumarin content was calculated using a molar absorptivity of 14,800 (Sondheimer, 1957). Titratable acidity (TA) was measured by titrating a $10-\mathrm{mL}$ juice sample to $\mathrm{pH} 8.2$ with $0.1 \mathrm{~N} \mathrm{KOH}$ and expressed as percent malic acid. Soluble solids content was measured using a refractometer (Atago N1, Tokyo).

Lettuce experiment. Iceberg lettuce was obtained from a local market. Handling and preparation of midrib tissue were according to Ke and Saltveit (1986). Eight segments placed in a petri dish served as a replicate and there were five replicates per treatment. The dishes containing lettuce midrib segments were treated with air or $42 \mu \mathrm{mol} \cdot \mathrm{m}^{-3} \mathrm{MCP}$ for $4 \mathrm{~h}$ at $6^{\circ} \mathrm{C}$ in sealed $4-\mathrm{L}$ glass jars. After treatment, the segments were stored in the jars at $6^{\circ} \mathrm{C}$ and humidified air with or without 126 $\mu \mathrm{mol} \cdot \mathrm{m}^{-3}$ ethylene was passed through the jars at $3 \mathrm{~L} \cdot \mathrm{h}^{-1}$. Respiration was measured as described above. Visual ratings of RS on a 0 9 scale (Ke and Saltveit, 1986), where $0=$ no injury and $9=>40 \%$ of the surface spotted, were performed $0,3,6$, and $9 \mathrm{~d}$ after treatment.

Statistical analysis. All experiments was conducted using a completely random design with four treatments and four (carrot) or five (lettuce) replicates per treatment. Data was subjected to analysis of variance and the least significant difference (LSD) procedure using SAS ver. 6.12 (SAS Institute, Cary, N.C.). Differences between any two treatments larger than the sum of two standard deviations were always significant (LSD, $P \leq 0.05$ ).

\section{Results and Discussion}

Effect of MCP on carrot respiration and acidity. Respiration rate of control and MCPtreated carrots changed little during the posttreatment period (Fig. 1A). Exposure to ethylene had stimulated respiration $4 \mathrm{~d}$ after treatment, while exposure to MCP for $4 \mathrm{~h}$ prior to ethylene treatment totally negated the ethylene effect. These results indicate that the rootperceived ethylene and that the ethylene-induced respiration rise may be processed via ethylene perception.

Ethylene treatment also reduced titratable acidity of juice $(0.083 \%$ control, $0.070 \%$ ethylene-treated). Treatment with MCP prior to exposure to ethylene prevented the acidity loss ( $0.083 \%$ MCP, $0.085 \%$ MCP + ethylene). There were no effects of the treatments on soluble solids content (data not shown).

Effect of MCP on carrot isocoumarin accumulation. The isocoumarin content was higher in carrot peel than in the pulp (Fig. $1 \mathrm{~B}$ and C) as previously reported (Lafuente et al., 1996). Isocoumarin content changed little in peel or pulp of control carrots during the posttreatment period. Treatment with MCP alone did not affect isocoumarin accumulation. Ethylene treatment stimulated isocoumarin accumulation, with the content in the peel increasing continuously during the $16-\mathrm{d}$ posttreatment period at $10^{\circ} \mathrm{C}$ and pulp contents reaching a maximum $12 \mathrm{~d}$ after treatment. After 16 $\mathrm{d}$ exposure to ethylene, isocoumarin content
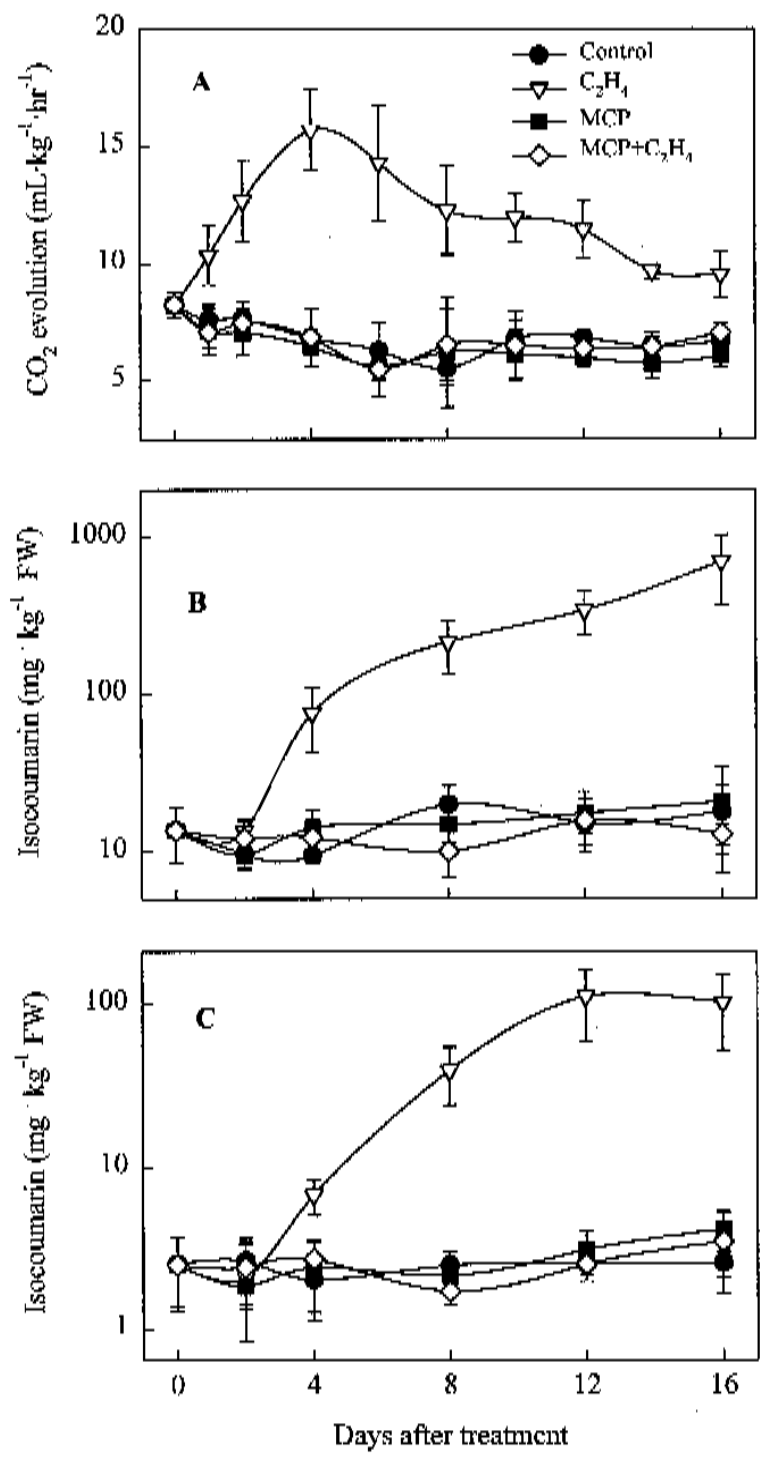

Fig. 1. Interactive effects of ethylene and MCP on respiration rate (A) and isocoumarin content of peel (B) and pulp (C) of 'Touchon' carrots at $10^{\circ} \mathrm{C}$. The roots were treated with: air (control); $42 \mu \mathrm{mol} \cdot \mathrm{m}^{-3} \mathrm{MCP}$ (MCP) for $4 \mathrm{~h} ; 42 \mu \mathrm{mol} \cdot \mathrm{m}^{-3}$ continuous ethylene $\left(\mathrm{C}_{2} \mathrm{H}_{4}\right)$; or $42 \mu \mathrm{mol} \cdot \mathrm{m}^{-3} \mathrm{MCP}$ for $4 \mathrm{~h}$, followed by 42 $\mu \mathrm{mol} \cdot \mathrm{m}^{-3}$ ethylene $\left(\mathrm{MCP}+\mathrm{C}_{2} \mathrm{H}_{4}\right)$. Vertical bars represent standard deviations.

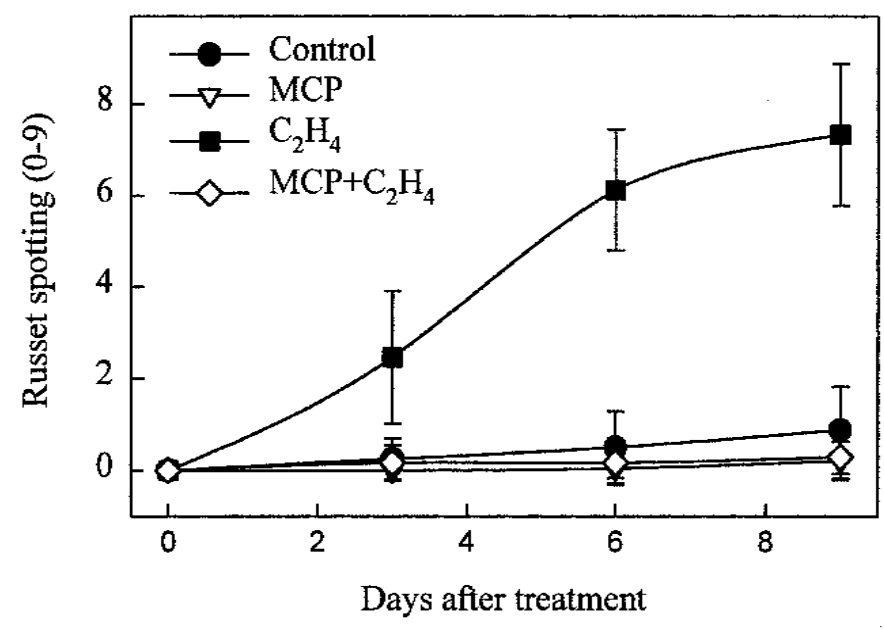

Fig. 2. Interactive effect of ethylene and MCP on russet spotting of midrib tissue of iceberg lettuce at $6{ }^{\circ} \mathrm{C}$. The tissue were treated with: air (control); $42 \mu \mathrm{mol} \cdot \mathrm{m}^{-3} \mathrm{MCP}(\mathrm{MCP})$ for $4 \mathrm{~h} ; 126 \mu \mathrm{mol}^{-3} \mathrm{~m}^{-3}$ continuous ethylene $\left(\mathrm{C}_{2} \mathrm{H}_{4}\right)$; or $42 \mu \mathrm{mol} \cdot \mathrm{m}^{-3} \mathrm{MCP}$ for $4 \mathrm{~h}$, followed by $126 \mu \mathrm{mol} \mathrm{m}^{-3}$ ethylene $\left(\mathrm{MCP}+\mathrm{C}_{2} \mathrm{H}_{4}\right)$. Vertical bars represent standard deviations. 
was 39 times as high as control in both peel and pulp, although the peel contained seven times more isocoumarin than the pulp. Treatment with MCP before exposure to ethylene totally eliminated the effect of ethylene on isocoumarin accumulation.

Effect of MCP on lettuce russet spotting. A small amount of RS developed in the midribs of lettuce during incubation at $6{ }^{\circ} \mathrm{C}$ in the absence of ethylene (Fig. 2). Exposure to ethylene stimulated RS development, while MCP treatment before exposure to ethylene prevented the increase. Treatment with MCP also prevented an ethylene-induced increase in respiration rate (data not shown).

Exposure to exogenous ethylene can stimulate many processes in plant tissues, including respiration. Although the mechanism is unknown, ethylene increases glycolytic intermediates and activity of fructose-6-phosphate 2kinase in carrots (Stitt et al., 1986). Nichols and Laties (1985) showed that this rise in respiration is not necessarily linked to ethylene induction of gene expression. The reduction in titratable acidity in carrots treated with ethylene may have been the result of increased respiration rate. Treatment with MCP reduces respiration rate and maintains acidity of apple fruit (Fan et al., 1999).

Isocoumarin, a phytoalexin implicated in development of resistance to carrot storage pathogens (Mercier et al., 1993), is synthesized from acetyl CoA and malonyl CoA through the polyketide pathway (Kurosaki and Nishi, 1988). Our results show that biosynthesis of ioscoumarin requires ethylene action. Treating carrots with MCP prior to exposure to ethylene eliminates accumulation of isocoumarin, although the mechanism of action is unclear.

Ethylene-induced RS development is associated with increased activity of PAL, POD, PPO, and IAA oxidase in lettuce. The inhibition of ethylene action may prevent this increase in activity. Cell wall thickening, tissue browning, and RS would then be inhibited. Low $\mathrm{O}_{2}$ (Ke and Saltveit, 1989) and exogenous application of IAA ( $\mathrm{Ke}$ and Saltveit, 1986) effectively inhibit RS development. Both low $\mathrm{O}_{2}$ and IAA may reduce $\mathrm{RS}$ development through inhibition of ethylene action (Ke and Saltveit, 1989).

Ethylene is important for the development of RS in lettuce and bitterness in carrots. Ethylene stimulates PAL activity in both carrot (Sarkar and Phan, 1974) and lettuce tissue (Hyodo et al., 1978); however, what initial process is signaled by ethylene or how ethyl- ene induces PAL and other enzymes is unclear.

Russet spotting in lettuce and the accumulation of isocoumarin can be induced by exposure to low concentrations of ethylene. A short-term MCP treatment before exposure eliminated the development of russet spotting and isocoumarin accumulation. MCP can be used as a fumigant to treat carrot and/or lettuce at harvest to prevent postharvest quality deterioration. In this experiment, MCP was applied at $42 \mu \mathrm{mol} \cdot \mathrm{m}^{-3}$ for $4 \mathrm{~h}$; this totally blocked any ethylene effect. Whether MCP can be used at lower concentrations, lower temperatures, or other treatment durations remains to be determined. Although it has great potential for commercial application, MCP has not been approved for use on food crops. Registration for use of MCP on ornamental crops was granted in the United States in 1999.

In summary, ethylene stimulated respiration in carrots and lettuce, isocoumarin accumulation in carrots, and RS development in lettuce. The increase in respiration, as well as isocoumarin accumulation and RS development, was prevented by MCP treatment prior to ethylene exposure. Other reports demonstrated that MCP inhibits ethylene-induced senescence of broccoli (Fan and Mattheis, 2000; Ku and Wills, 1999). The reduction in ethylene action induced by MCP treatment may be a useful means to prevent undesirable ethylene effects during storage of many vegetables.

\section{Literature Cited}

Abdi, N., W.B. McGlasson, P. Holford, M. Williams, and Y. Mizrahi. 1998. Response of climacteric and suppressed-climacteric plums to treatment with propylene and 1-methylcylcopropene. Postharvest Biol. Technol. 14:29-39.

Carlton, B.C., C.E. Peterson, and N.E. Tolbert. 1961. Effects of ethylene and oxygen on production of a bitter compound by carrot roots. Plant Physiol. 36:550-552.

Chalutz, E., J.E. Devay, and E.C. Maxie. 1969. Ethylene-induced isocoumarin formation in carrot root tissue. Plant Physiol. 44:235-241.

Fan, X., S. Blankenship, and J.P. Mattheis. 1999. MCP inhibits apple fruit ripening. J. Amer. Soc. Hort. Sci. 124:690-695.

Fan, X. and J.P. Mattheis. 2000. Yellowing of broccoli in storage is reduced by 1-methylcyclopropene. HortScience 35:885-887.

Golding, J.B., D. Shearer, S.G. Wyllie, and W.B. McGlasson. 1998. Application of 1-MCP and propylene to identify ethylene-dependent ripening processes in mature banana fruit. Postharvest Biol. Technol. 14:87-98.

Hyodo, H., H. Kuroda, and S.F. Yang. 1978. Induc- tion of phenylalanine ammonia-lyase and increase in phenolics in lettuce leaves in relation to the development of russet spotting caused by ethylene. Plant Physiol. 62:31-35.

Ke, D. and M.E. Saltveit. 1986. Effect of calcium and auxin on russet spotting and phenylalanine ammonia-lyase activity in iceberg lettuce. HortScience 21:1169-1171.

Ke, D. and M.E. Saltveit. 1989. Regulation of russet spotting, phenolic metabolism, and IAA oxidase by low oxygen in iceberg lettuce. J. Amer. Soc. Hort. Sci. 114:638-642.

Ku, V.V.V. and R.B.H. Wills. 1999. Effect of 1methylcyclopropene on the storage life of broccoli. Postharvest Biol. Technol. 17:127-132.

Kurosaki, F. and A. Nishi. 1988. A methyltransferase for synthesis of phytoalexin 6-methoxymellein in carrot cells. Federation European Biochem. Soc. Lett. 227:183-186.

Lafuente, M.T., G. Lopez-Galvez, M. Cantwell, and S.F. Yang. 1996. Factors influencing ethyleneinduced isocoumarin formation and increased respiration in carrots. J. Amer. Soc. Hort. Sci. 121:537-542.

Link, G.K.K. and M.W. Gardner. 1919. Market pathology and market diseases of vegetables. Phytopathology 9:497-520.

Mercier, J., J. Arul, and C. Julien. 1993. Effect of UV-C on phytoalexin accumulation and resistance to Botrytis cinerea in stored carrots. J. Phytopathol. 139:17-25

Nichols, S.E. and G.G. Laties. 1985. Differential control of ethylene-induced gene expression and respiration in carrot roots. Plant Physiol. 77:753-757.

Porat, R., B. Weiss, L. Cohen, A. Daus, R. Goren, and S. Droby. 1999. Effects of ethylene and 1methylcyclopropene on the postharvest qualities of 'Shamouti' oranges. Postharvest Biol. Technol. 15:155-163.

Rood, P. 1956. Relation of ethylene and post-harvest temperature to brown spot of lettuce. Proc. Amer. Soc. Hort. Sci. 68:296-303.

Sarkar, S.K. and C.T. Phan. 1974. Effect of ethylene on the phenylalanine ammonia-lyase activity of carrot tissues. Physiol. Plant. 32:318-321.

Sisler, E.C. and S.M. Blankenship. 1996. Method of counteracting an ethylene response in plants. U.S. Patent No. 5,518,988.

Sisler, E.C. and M. Serek. 1997. Inhibitors of ethylene responses in plants at the receptor level: Recent developments. Physiol. Plant. 100:577582.

Stitt, M., C. Cseke, and B. Buchanan. 1986. Ethyleneinduced increase in fructose-2,6-bisphosphate in plant storage tissues. Plant Physiol. 80:246-248.

Sondheimer, E. 1957. The isolation and identification of 3-methyl-6-methoxy-8-hydroxy-3,4dihydroisocoumarin from carrots. J. Amer. Chem. Soc. 79:5036-5039.

Theologis, A. and G.G. Laties. 1982. Potentiating effect of pure oxygen in the enhancement of respiration by ethylene in plant storage organs: A comparative study. Plant Physiol. 69:1031-1035. 